\title{
An Analysis of Gender Equality of Chinese Culture in Mulan Film (2020)
}

\author{
Sirikit A. Usman \\ English Literature Department \\ Universitas Muhammadiyah Gorontalo \\ Indonesia \\ ausmansirikit@gmail.com \\ Mifta Sulistia Tamola \\ English Literature Department \\ Universitas Muhammadiyah Gorontalo \\ Indonesia
}

\author{
Meis Sintia Umar \\ English Literature Department \\ Universitas Muhammadiyah Gorontalo \\ Indonesia
}

\author{
Ridho Ishak \\ English Literature Department \\ Universitas Muhammadiyah Gorontalo \\ Indonesia
}

Citation: Usman, A. S., Umar, M. S., Tamola, M. S., \& Ishak, R. (2021). An analysis of gender equality of Chinese culture in Mulan Film (2020). Notion: Journal of Linguistics, Literature, and Culture, Vol 3(2), p. 75-80. http://doi.org/hotion.v3i2.4886

\section{Article Info}

Article History

- Article Received September $20^{\text {th }}, 2021$

- Article Accepted October $30^{\text {th }}, 2021$

\section{Keywords}

Gender Equality

Chinese Culture

Discrimination

Film

Feminism

\section{ABSTRACT}

Mulan film (2020) raises gender issues and is still related to the laws of norms and traditions. Mulan has a strong and patriarchal nature while Chinese cultural traditions are not unilateral with Mulan figures. The study aims to promote justice for women with regard to Chinese culture and traditions, as well as whether it has the opportunity to promote equal treatment without discrimination. Gender equality is commonplace to raise and talk about. Each gender is formed in a complex culture of each gender either in their respective positions or positions. Gender equality is linked to feminist, masculine and also includes sexism. Women and men can change roles like women can be wise leaders and men can do the skills that women have such as cooking. This study uses qualitative descriptive methods to analyze the social circumstances associated with the scene. Researchers use the technique of observing the film, interpreting each situation in the film, then collecting data, seeking information on gender equality or activities through observation and sensing that are still related to gender equality in culture, After that give a view on the object to be observed. Thus the research of Mulan film (2020) is intended to find a new mindset or an idea and a new understanding. This method uses observation and sensing and then provides a new interpretation. 


\section{Usman, A. S., Umar, M. S., Tamola, M. S., \& Ishak, R. An Analysis of Gender Equality of Chinese Culture in Mulan Film (2020)}

\section{INTRODUCTION}

Film as we know is something that is shown in a visual form. Where our society also often watch movies, either on television or by coming to the cinema. Movies are liked by all groups of people. The film displays content that is liked by the public from small children to adults. Films usually provide entertainment, ideas, knowledge, and also represent a culture. Films are taken based on true stories, fiction, legends, myths, and other stories to be adapted to the big screen and remade in such a way that they can be published to the general public.

Film is also referred to as moving images on a screen or moving images in the form of video and displayed on a screen. Film is a literary device that resembles prose, but the film is in the form of a visual screen. This is what distinguishes film from other literary devices such as drama, theater, and prose. Film is a means to convey messages. In law no. 8 of 1992 regarding film reads:

"Films are artistic and cultural copyrighted works which are visual-hearing mass media which are based on the principle of cinematography by recording celluloid tape, video tape, video accompaniment, and or other technological inventions in all forms, types and sizes through chemical processes, electronic processes, or other processes with or without sound that can be displayed and or displayed with electronic and or other mechanical projection systems."

So films can be a means of conveying messages and connecting people with culture that are displayed in visual form. Films have the opportunity to present and spread something about culture. There is also a lot to be learned from films that have cultural elements that contain gender equality. The films that we watch have many choices, one of which is the Mulan film (2020) which is one of Walt Disney's films. Walt Disney produced Mulan film in 2020 which is a remake of the animated version of Mulan (1998). The Mulan film 2020 tells of her struggle to replace her father in going to war, because Mulan feels sorry for her old father who should no longer go to war. So Mulan was moved to replace him, she hid behind a man's appearance. This was for his father's sake despite having to break the laws and traditions of the time.

The Mulan film shows Chinese culture at that time how women were placed in their rightful nature. Women behave like women from clothing, decoration, manners and all things also related to household matters. The film shows that it is men who have power over everything, from leading to decisions that must be based on men. Mulan goes against tradition, causing problems between herself and her family.

The purpose of this research is to explore gender equality in Chinese culture whether tradition can accept the changes brought from Mulan and other characters from the scene in the Mulan film 2020. The researcher also aims to know the laws and traditions and also to know that women have the same opportunities as men, in order to get equality. The same rights as men.

Culture is a life view of a group of people in the form of behaviors, beliefs, values, and symbols that they receive involuntarily all of which are passed down through the process of communication from one generation to the next one[3]. From the Chinese view of Confucianism, The essence of teaching is to regulate the relationship between people with their respective status. A prayer for people to behave and act in living life[1].

Feminism is an understanding or tradition that continue demands equality or equalizing women's rights with men. In this case women feel they have been bullied by men[4]. Characteristic of masculine can be described as a strong individual figure, firm, and brave. Individual that identified as masculine creature have an independent nature, steadfast, strong spirit of curiosity, self-confidence and also the courage to take a risk[6]. Natasha Walter defines sexism as "discrimination committed against others based on gender or gender, mostly women"[5].

\section{METHODOLOGY}

The method used in this study is qualitative descriptive method. According to Moleong[7] using descriptive method means that researchers analyze the data collected can be words, pictures and not 
numbers. The data may come from interview manuscripts, field records, photographs, video tapes, personal documents, notes or memos and other official documents[3].Researchers used that understanding to observe behaviors and storylines. Researchers will describe and explore things in the film that are still related to the culture in Mulan film and related to gender equality, then after describing things in the film researchers give a proper interpretation.

First observing Mulan film (2020), researchers understood each scene whether there was a sense of being focused on the issues of feminism, female masculinity and sexism. Then after that the researchers used qualitative descriptive studies by observing the writing and behavior of the characters or objects in the film to be observed. Researchers collects data on behavior, dialogue, proverbs and records based on findings when collecting data. It then gives a view of the action and dialogue in the film.

\section{RESULT AND DISCUSSION}

Movies are very likely to elevate the life of a society. Rules and ways of life are conveyed expressly or impliedly. From the researcher's analysis of Mulan film (2020) it can be interpreted that the traditional society in the film holds Confucius ideology, it is clearly implied that the Confucius view shown in the film illustrates that it is very important for the position of men in an environment. It is also closely related to the yin-yang principle, which is that superior males and females are inferior. In terms of traditional understanding in the film that men are very influential on the dignity of the family if they have daughters then their job is to bring honor because women are disgrace and shame. From the results of the analysis the researchers include the following images:

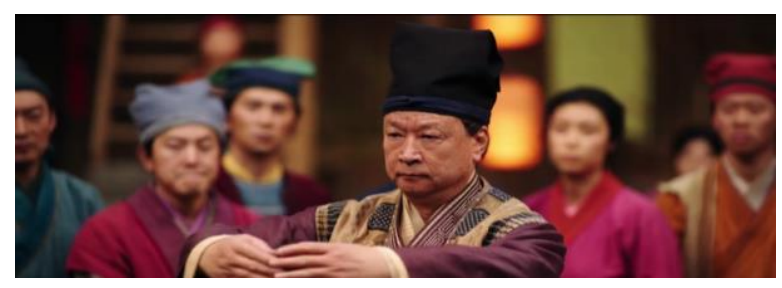

Picture 1.

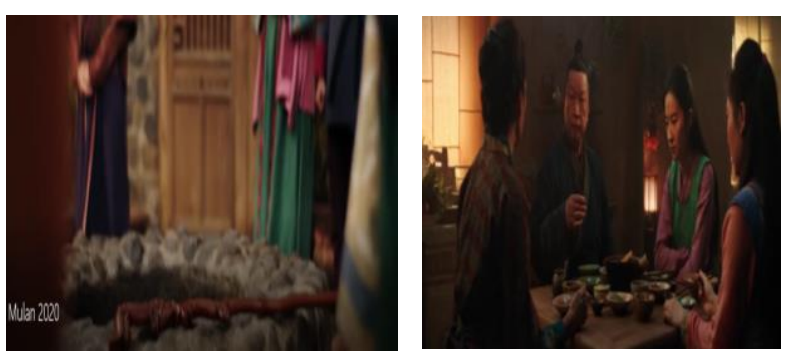

Picture 2.

The use of the image, the man was born strong as in the principle of "the" good as old as anything if men then there is no reason for refusal to follow conscription because the pride of men is in the position of social or political. Then the father or male position is central then every decision must have the consent of the father or the man in the family.

Based on the results of the analysis that in Chinese culture, there are differences in the position of women and men in doing something. It is seen from Confucius's view that the woman is obedient and is in the lower layer or low position. At that time women's lives were quite difficult, women were burdened with respect through marriage and family shame then from some figures between Mulan (hua Mulan) and her sister (Hua Xiu). Xiu and Mulan are brothers who get along with different traits. Mulan behaved like a man and Xiu behaved normally like a female woman at the time, he was afraid to fight their laws and norms.

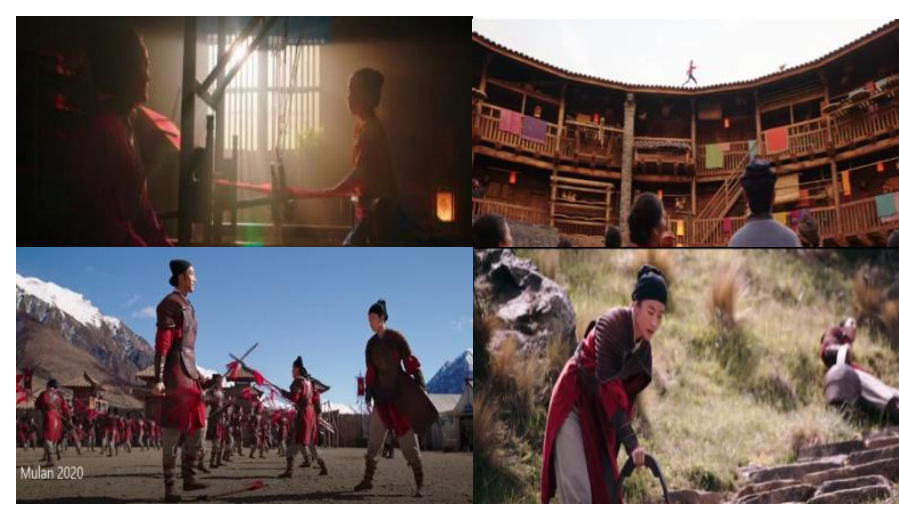

Picture 3.

China's cosmological principle of yin and yang (Budaya \& Kuno, n.d.) is still related to confuciusism. Researchers analyzed from the first image, Xiu is a representation of yin. Xiu is weak, obedient, more accepting of circumstances. In addition, researchers also found from the film, Mulan is the only character who portrays a masculinity in women. Her carrying is 
strong, nimble, courageous, assertive and self-reliant. Shown in the film there is a female masculinity in the film is not only bold, confident and independent but also strong physical in the sense of athletic, aggressive and competitive. From the observations and analysis evidenced by the natural female masculinity of Mulan film not only in terms of its nature but can be characterized by her courage to change her appearance to a man. Mulan's masculine behavior is characterized by the clothes he wears, in addition to the analysis of the film that has been collected, there is an idea of feminism from the film that is observed in Mulan film with his high self-confidence and strong grace, being able to be a soldier even he brings honor not a tradition line.

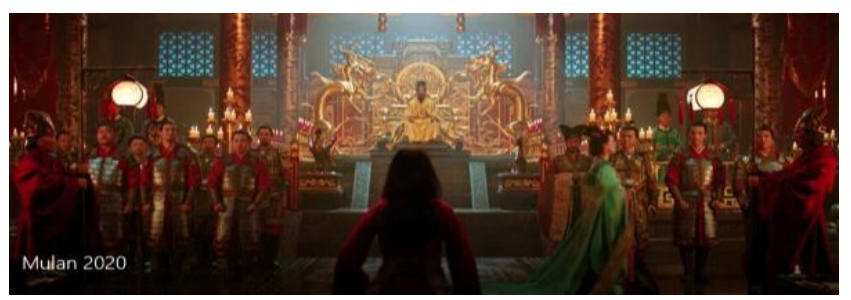

Picture 4.

(The tradition of honor for women to be graceful, marry and take care of the family)

The honor that Mulan found because of courage, loyalty, and honesty Mulan dare to accept all risks in order to get the results of what was done. This result was an unsought achievement, although she was a disgrace during his conscription, but he showed greatness and outstanding leadership to achieve satisfactory results.

So the understanding arises that women are able to have the opportunity to have the right to do the same as men. From the film scene, the king gives Mulan an honor for the country, this raises the perception that there is nothing weak between two genders, nothing special or hates men. This equality is intended to find equal opportunities between men and women is evidenced by the achievements of the character Mulan.

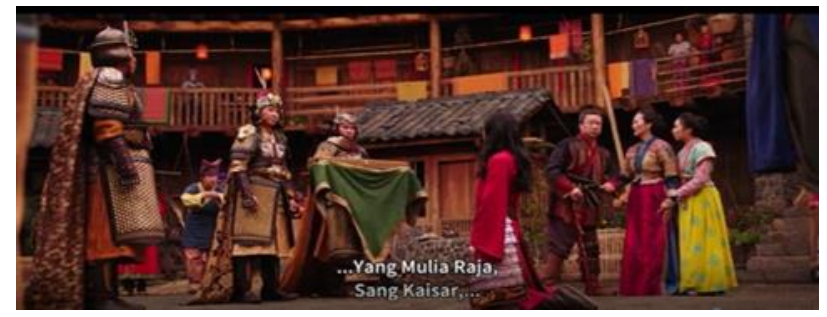

Picture 5.

Other results found different welcoming scenes and people's views on Mulan's arrival, plus the arrival of military commanders giving souvenirs in the form of swords with three word carvings that are the ancestral principles of the Hua family. Thus a new meaning arose, Mulan as the driver of women's equality at that time, changed the mindset of society that as a woman there is no prohibition to do the same as men. Researchers note traditional rules or traditions can be flexible although they cannot actually be changed but over time there will be adjustments to traditions with their adherents.

Plus, the film raises one of the issues of gender equality, namely sexism. Sexism is closely related to discrimination against women, one of the scenes in the film shows that men have better judgment than women. The researchers found that if the mindset of sexism was contrary to conservative views then traditional Chinese values at the time illustrated that male standing was very important, either in the family or leading in a wide environmental scope. Mulan film (2020) describes the principle of Confucianism, yinyang highly positioning father or male.

Based on the above analysis, Mulan film researchers alluded to the rules or mindsets of Chinese traditions that do not free women to choose as they see fit. As a result Mulan's character managed to provide a change of circumstances, his great confidence and courage. Mulan earned an honorable place, the opinion that women should be guardians of honor can be obtained without marriage but can be through positive abilities that are honed talents that bring new achievements. 
In addition, this film also raises one of the issues of gender equality, namely sexism. Sexism goes against society's aspirations for gender equality. Sexism itself is also touted as the root of the problem of gender inequality because it is related to the inequality of public understanding of the condition of men and women. This understanding is then realized in the form of treatment and rules. This rule is directed at traditional (old) laws and regulations that can cause discrimination and harm women. Therefore, the Mulan film (2020) provides a mindset about women in society where women are not always considered physically or non-physically weak. The Mulan film provides awareness that all genders can have all rights to achieve prosperity. This film provides an awareness that women are not always in a cultural sphere where women are intended only to marry and take care of the family as a real example that in this world, women and men are capable of exchanging roles. This is a fact that is often seen in our eyes where now women are able to become leaders, which are usually positioned by men and vice versa, men can also do the tasks that women have, one of which is cooking. This also happened to Mulan's character who was also able to become a leader in the military.

Then, the film shows that men have better judgment than women. The scrutiny of the entire Mulan film (2020), found that if the mindset of sexism contrasted with conservative views then traditional Chinese values at the time illustrated that the position of men was very important, either in the family or leading in a wide environmental scope. In the film, the public is a group that rejects gender equality. This society and its traditional rules or traditions, bring a thought if the woman is something weak. Then it has no freedom to go forward. Society clearly refuses if there are women who are different from other women for example such as Mulan assertive, nimble and spirited leaders. The problem of sexism is faced by the figures of Mulan and Xianning.

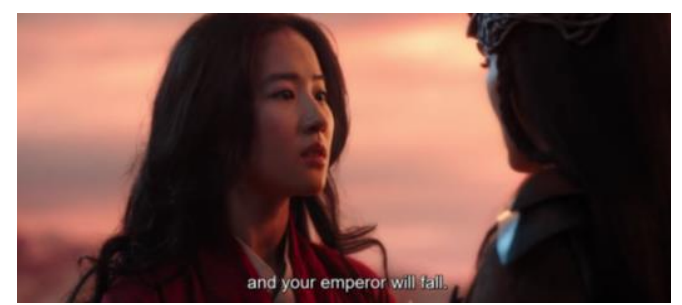

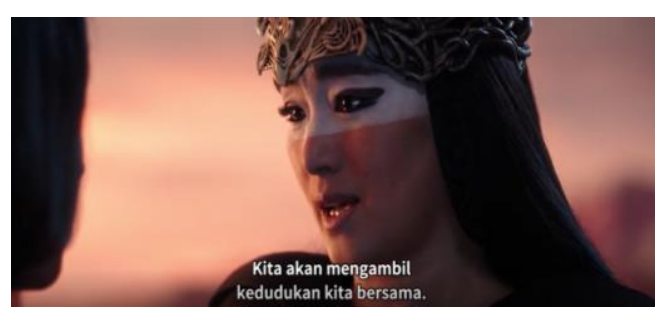

Picture 6.

You can never go home, you disgrace is worse than death.

I understand, I was a girl like you when people turned on me.

You don't think I longed for a noble path?

I've lived a life of exile. No country, no village, no family, we same.

The more power I showed, the more I was crushed, just like you

You save them today and still they turned on you.

The scene pieces and dialogue above express the form of female discrimination. Society has not received properly if women differ from the path provided in the culture (in ancient Chinese rules or traditions) society is not easy and does not quickly adjust to different circumstances. Different women will be given social exclusion. Xianning's situation and her past in society formed an invitation for cooperation with Mulan but Mulan refused, in the end Xianning supported and helped her at the end of the story. This is considered the effect of sexism that gave rise to the feminism movement. In the end, gender equality was achieved by the main characters. Prejudice about women also changes in the social eye in the film.

\section{CONCLUSION}

In a short, the film Mulan (2020) is a film produced by Walt Disney, presenting the gender equality movement and ancient Chinese culture. Namely the Confucian understanding that focuses on the male gender is very important. in the film Mulan (2020) there is a contrast between culture, namely traditional understanding and the stereotype of gender equality for women, namely feminism, masculine and sexism. In the sense of feminism, Mulan shows the equalization of women's rights so they don't feel like they are tortured by the thought that women and men are different, where women should not be superior to men. Then the film also describes the masculinity of 
women who are brave, tough, independent, strong and like to compete. Mulan's film further refers to the issue of sexism which discriminates that women should not do things that are considered strong. Thus, women do not always have to be constrained by ancestral law which requires them to act according to their position.Traditional laws and their ancestors must be obeyed but Mulan can provide an open view, to change the social mindset of society regarding the thought of women who are considered too weak.

\section{REFERENCES}

[1] Asruchin, D. M. (2018). Konfusianisme: sumber peradaban China. The First International Seminar \& Roundtable Meeting "Professional Chinese Teaching" in Southeast Asia, 75-84. https://china.uai.ac.id/wpcontent/uploads/2019/02/July-2018-UAIPBM-International-Seminar-

Proceeding.pdf $\#$ page $=82$

[2] Budaya, D., \& Kuno, C. (1997). In Irwan Abdullah, "Dari Domestik ke Publik: Jalan Panjang Pencarian Identitas Perempuan", dalam Irwan Abdullah (ed.), Sangkan Paran Gender, p. 311-314. Yogyakarta: Pustaka Pelajar.

[3] Indrastuti, N. S. K. (2018). Representasi Unsur Budaya dalam Cerita Rakyat Indonesia: Kajian Terhadap Status Sosial dan Kebudayaan Masyarakat. Malaysian Journal of Social Sciences and Humanities (MJ - SSH), 3(3), p. 192. https://msocialsciences.com/index.php/mjssh/ article/view/124

[4] Manurung, D. (2013). Analisis unsur feminisme dalam kumpulan cerpen perempuan berlipstik kapur karya esti nuryanti kasam. Journal UMRAH. https://jurnal.umrah.ac.id/archives/688

[5] Korompot S. N. (2017). Representasi seksisme dalam fim Her. Thesis, p. 97. https://core.ac.uk/display/89564717

[6] Sulistia, R. (2016). Female masculinity of Fa Mulan and its impact towards her relationship with male characters in disney movie Mulan. Litera $\sim$ Kultura, 4(3), 12-19. https://core.ac.uk/download/pdf/230653305.p $\underline{\mathrm{df}}$
[7] Moleong, L. J. (2001). Metode penelitian kualitatif. Bandung: PT Penerbit Remaja Rosdakarya. 